\title{
Agricultural Crises in sub-Saharan Africa: Capitalism and Transitions to Socialism
}

\author{
Reginald Herbold Green
}

A nation which is dependent on another country for the food consumption of its population cannot but be a dependent hostage of the particular country which feeds its population.

SWAPO of Namibia, Political Programme

Our own reality - however fine and attractive the reality of others may be - can only be transformed by detailed knowledge of it, by our own effort, by our own sacrifices. .

Amilcar Cabral, late President PAIGC (Cape Verde-Guinea Bissau)

If the people are to develop they must have power. They must be able to control their own activities within the framework of their village communities ... At present the best intentioned goverments my own included - too readily move from a conviction of the need for rural development into acting as if the people had no ideas of their own. This is quite wrong ... people do know what their basic needs are ... if they have sufficient freedom they can be relied upon to determine their own priorities of development.

Julius K. Nyerere, President of Tanzania

\section{Crisis or Crises? In Production, Prices, Procurement?}

The performance record of African agriculture over 1970-80 is not satisfactory [see for example World Bank 1981; Harvey 1981]. While dat a are fragmentary and open to manipulation, the broad picture is of an average rate trend of food production growth of around 2.5 per cent a year, against 3.0-3.5 per cent for population. In a majority of sub-Saharan African countries there is a clear trend-towards lower per capita food production and a rise in per capita food imports. For industrial/export (so-called 'cash') crops the record is worse, with a trend growth rate barely above two per cent.

To generalise is dangerous - albeit inevitable in a short survey. Country records and experiences differ radically. So do year to year performances (eg to 1980,

\footnotetext{
${ }^{1}$ Cash/food crop is the traditional dichotomy but a very bad one, as the majority of African peasant households' cash income comes primarily from sale of food crops or animals for local consumption.
}

Zimbabwe's agricultural output growth was below population) and those by crop (eg Tanzania's trend annual coffee output growth over 1976-81 is 4.8 per cent and cashew nut minus 12 per cent). Statistical dat a are very weak, and hard to interpret without going back to check coverage, primary sources and methodology. ${ }^{2}$ This is not a reason for avoiding any attempt at analysis but it is a reason for caution in reaching firm conclusions, for avoiding sweeping generalisations, for looking at the particular and for scepticism about the analysis of others (especially if one approves of its conclusions) and self-doubt about one's own analysis.

Whatever the reason, production performance is not satisfactory at sub-regional or, for most states, national level. Given the crushing foreign balance constraints following a radical structural worsening of external terms of trade, both the buoyant food import and the stagnant export side of the current account scissors resulting from agricultural problems are almost as serious as, or in some cases more serious than, the nutritional ${ }^{3}$ and rural income implications. Certainly the weather (either by a worse average over the 1970s than during the period $1930-70$ or by change in the number of consecutive good or bad years) and socio-political instability (including war) have been substantial contributory causes. However, they cannot account for the whole difference between the achieved and - say - a four to five per cent growth rate and, even if they could, there would be a pressing need to see how better output performance could be regained.

Terms of trade have been a major factor. Over 1972-76 and 1977-81 a majority of African economies sustained a halving of the real unit external purchasing power of their agricultural exports. Not surprisingly - except perhaps - judging by some analysis and advice - to sections of the IMF and World Bank - this reduced their domestic purchasing power and

\footnotetext{
${ }^{2} \mathrm{Eg}$, the share of commercialised peasant rice passing through official channels in Tanzania was near 100 per cent, by 1982 it is near zero per cent. Thus marketed paddy has gone from about $70-225$ thousand tonnes but official channel data show 75-25 (state farm in the latter year).

${ }^{3}$ Recent Tanzania data suggest some nutritional improvement over 1970-80, while Ugandan rural data suggest that areas not enmeshed in actual civil disturbances are not experiencing radically worse nutritional situations than a decade ago.
} 
explains why output of export crops has on balance lagged behind food production. There is clear evidence of cross elasticities among crops. That is, shifts occurred among crops produced in response to alterations of their relative prices, albeit neither in as simple nor dominant a form as some commentaries, notably the World Bank's Accelerated Development in sub-Saharan Africa, suggest. ${ }^{4}$ Domestic terms of trade shifts - whether measured in peasant prices/urban goods prices or peasant prices/urban wages - have not been uniform. While in most cases the rural side has gone down, this is not universal (especially over 1975-80). ${ }^{5}$ Nor does there seem to be a simple correlation between overall urban/rural terms of trade and output growth. This is not, perhaps, as surprising as it seems for peasants do not usually have much 'spare' labour or other key resources at peak requirements times, so that higher real average prices alone are unlikely to result in a massive increase in output (the contrary view has been argued - to a degree in Accelerated Development [World Bank 1981] and more forcefully by the Bank's Uma Lele).

On the other hand, even if 'getting the prices right' seems less central - and, by itself, less successful than is sometimes argued, there is a case for arguing that 'achieved production failures' do not relate primarily to peasant ability to produce, still less to 'lazy', 'stubborn' or 'stupid' peasants, but are much more closely related to growing weaknesses in input supply, transport, storage, procurement and availability of actually desired, non-household produceable use values ('incentive goods'). Weaknesses in research, extension and technological change are not listed separately, partly because they were no worse in the 1970 s than before and can thus hardly cause the worsening performance, and partly because on past record and present expert proposals they seem unlikely to be a relevant part of the cure in the $1980 \mathrm{~s}-$ except in certain special cases relating to seeds, implements and epidemic disease control chemicals, usefully subsumed under inputs.

Transport deterioration (closely related to fuel and vehicle prices) has slowed, limited or prevented marketing of produced crops (and thus deterred

\footnotetext{
${ }^{4}$ Raising real cashew nut prices in Tanzania by about $571 / 2$ per cent over 1979-81 raised output 40 per cent in the first year, but a 20 per cent fall followed, despite the second half of the real price boost. Cotton acreage has not declined significantly over 1970-80 despite a real price fall of over 50 per cent.

sIn Tanzania, for example, 1967-70 and 1975-80 saw significant urban to rural shifts (eg over 1975-80 peasant producer prices rose by at least 40 per cent relative to the minimum wage, and 60 per cent relative to publiz sector salaries) while $1970-74$ showed an opposite swing so that 1966 and 1980 producer price/minimum wage ratios show no real trend, and 1969-76 saw a reduction in urban/rural household income inequality. This is not typical, judging by price data given in World Bank 1981 and Harvey et al 1981, but is also probably not unique.
}

subsequent production). Equally it has rendered the supply of input and consumer goods erratic and untimely. In addition, import constraints, failure to allocate resources to developing and extending appropriate seed, tool, disease and pest control programmes and - in a majority of cases - 'urban bias' in relative prices and/or allocations whether through bureaucratic, 'free' or 'parallel' markets have had the effect of depriving agriculture both of inputs and of use values (urban goods/services) which provide peasant households with an incentive to engage in petty commodity production. It is no accident that except in cases of natural or human disaster (eg drought, war) rural food availability and nutrition has not worsened much - the secular increase in food crises or imports in Africa is predominantly urban. This does not reduce the reality of the crisis, but does raise questions as to its causes.

Procurement - both public and private sector - has also worsened in many cases. In the first place buyers are less readily and reliably available and less likely to pay cash on the spot. In Mozambique, for example, the departing colons took the rural commercial and transport system with them, in Tanzania transport and financial constraints radically worsened the rural purchase-collection-payment records of most parastatals. In many cases disturbances (economic, military, political) created 'choke points' at which a handful of merchants could take control of the process of commercialisation, allowing monopoly exploitation of peasants. Both the food and coffee aspects of Uganda magendo, for example, especially at its 198081 'high' as a dominant sub-mode of production rather than a secondary parallel market sub-system, turned on the exploitation of such 'choke points' as do somewhat analogous situations in Zaire [see Green 1981].

Storage debacles - centering on failure to expand capacity and inappropriate selection of type and location - have worsened transport bottlenecks by preventing the smoothing of seasonal peaks in the movement of inputs, crops and incentive goods and by forcing (or at least encouraging) some procurement agencies to move crops 'early and often' rather than to hold at purchase point until a use point was clearly identified. Horror stories of cross transport, back and forth movement of the same grain, etc, abound. In Tanzania arguably 150 to 200 per cent of the necessary tonne mileage has been used with a high monetary and opportunity cost in fuel and vehicles. Storage problems have also led to catastrophic losses especially in the urban and national reserve subsectors - eg, 600,000 tonnes physically destroyed, deteriorated and used as poultry feed or exported at one-fifth domestic food value to avert physical loss in Tanzania over 1977-80. Contrary to conventional wisdom, 
typical peasant storage has relatively low losses and moderate quantative adequacy (unless there are several successive good seasons).

That these factors seem to have had a greater effect on long distance (urban) supply is not surprising. African urban populations have exploded upwards, rising, eg from three to 18 per cent in Tanzania over 1960-80, and from 15 to 45 per cent in Zambia) but neither the public nor the private procurement, marketing and storage systems have undergone any similar structural transformation. As a recent World Bank Assistance Group report on Tanzania argues, the problem does not seem to be primarily peasant ability or even willingness to produce, but 'modern' sector inability to procure, hold, move and distribute.

The state role in all this is complex - as the varying terms of peasant price/urban wage trends suggest. It is not limited to procurement or to 'urban' vs 'rural' bias, much less to capitalist versus socialist orientation. Three other critical issues turning on the state are: ability to keep an orderly, stable state mechanism of some variety functioning as against a descent into a 'magendo' dominated rural commercial economy (or a wasteland ravaged by invasions in certain cases); ability to procure enough import capacity to operate the economy (including agriculture, processing, transport 'incentive goods') at anything like existing capacity; skill in relating rural resource allocations to short as well as longer-term production. ${ }^{6}$

\section{Toward a Rural Bourgeoisie?}

One approach to crisis resolution would be to back the emergent African rural petty bourgeoisie/kulak/ functionary sub-class alliance. This could be based on a standard capitalist modernisation and production ideology, ${ }^{7}$ on a more sophisticated African rural development/production growth/household-clanstate redistribution model, (an example may be Botswana) or on a nakedly exploitative, short-term interests of power holder approach like the rural side of Ngugi's Petals of Blood. In the first line of argument, modern inputs in the hands of entrepreneurs freed of traditional and state restraints is seen as necessary and largely sufficient to achieve rapid growth. In the second, the progressive capitalist farmers are seen as adding to - rather than substituting for - preexisting output, and as strengthening the income security of the rural poor by intra-extended family and

\footnotetext{
${ }^{6} \mathrm{Eg}$, basic public services (including education) may be critical to longer-term production trend increases, but not very relevant to short-term goals.

${ }^{7}$ An expatriate example is E. Berg whose basic position - somewhat water ed down, especially by addition - is at the core of Accelerated Development [World Bank 1981], and an official African one is Kenya's famous Sessional Paper 10 on African Socialism [Government Printer, Nairobi, 1965].
}

clan transfers. In the third, concentration of wealth and power is seen as the way to achieve rapid economic change and the breaking of non-economistic links such as obligations to family clan as positive in ensuring maximum growth, accumulation and modernisation. However, it could also be an approach favoured by socialists for one of two reasons. First, that a capitalist transition was needed to create the productive force levels adequate for a transition to socialism, or second, to create the production relations and levels of visible local capitalist exploitation and of antagonistic contradictions necessary to achieve a revolution. ${ }^{8}$

The ultimate problem with these rationales - except perhaps the last - is that the 1970-80 record offers little convincing evidence that a capitalist transformation in African agriculture is likely to be achievable, sustainable or effective in achieving a rise in trend growth rates to the four to five per cent range. Certainly the data collected in the Annex to the Bank study show how rarely this has happened to date. The main variants of capitalist transition are 'neokulakism' ('progressive farmer', 'modernising peasant' etc); plantation and settler/'modern farm'. Although each has some striking short-term success - at least in its own terms - none looks generally promising in Africa of the 1980s.

Neo-kulakism has its best record in export-oriented and especially (not exclusively) tree crop production under Smith/Myint 'vent for surplus' conditions [Myint 1958]. It has formed the basis for most initial export boom changes in agricultural production in Africa (eg Ghana 1880-1910, Ivory Coast 1960-70, Tanzania 1960-66, Botswana 1965-75 and, with heavy state stock capital, Sudan 1950-65). But it has had a distinct tendency to plateau at relatively low levels, whether for external (terms of trade, food and labour supply, land availability) or ecological reasons. In any case, it is not clear that the neo-kulak element is critical under present and foreseeable African technology/support services/marketing conditions. 'Pure' peasants with little non-household labour (or an exchange of labour among households) are not demonstrably less effective at raising productive forces, even if they are less effective at gaining access to inputs and markets in a basically zero sum game contradiction with neo-kulaks. Many of the latter in certain post-1945 contexts have been 'economic

\footnotetext{
${ }^{8}$ Both themes are present in Marx and in African Marxian writers like Samir Amin. Extreme variants - eg the ultra-orthodoxy of Bill Warren for the first, and the tactical capitalist road advocacy of some Trotskyites for the second - arguably distort, as do the "world system analysts' (notably E. Wallerstein) who argue that attempted socialist transitions sustained by neo-mercantilism on the periphery strengthen capitalism at the centre and as a global system, and should, therefore, be avoided (ie state power should not be struggled for).
} 
activists', in trade or co-operative bodies, rather than peasants, before acquiring land, and have neither peasant nor modern farmer skills in land use.

The successes in raising marketed staple food production by this route are fewer. The Ivory Coast may be one (albeit less so in recent years, judging by GDP and grain import data). One reason for this is illustrated by the large-scale maize farmers of Ismani in Tanzania - they were land grabbers and miners who acquired and ruined good land over six years (poor peasants did neither) and moved on - a way to capitalist accumulation perhaps, but not to sustained output growth. Similar problems arise in respect to annual industrial/export crops, eg cotton (for soil type and economically viable commercial rotation reasons) and tobacco (because of fuel requirements) in Tanzania.

World Bank and similar small farmer schemes, at their best, are in fact 'neo-kulak' oriented, even if this is not intended [see Wallace 1980]. They do benefit some labour-employing commercial farmers. But they suffer from such high costs per acre, such egregious technical errors (related to the data and analytical base) and, often, from such large unanticipated negative output effects outside the schemes [Wallace 1980] as to raise grave doubts whether their overall production impact is much more positive than their (clearly negative) influence on income distribution. The clear exceptions in the Sudan and Egypt do not appear to be widely replicable. At their worse such small farmer schemes reduce peasants to penury (eg Fleuve schemes in Senegal) or are disguised plantations (disguised to outsiders, not to peasants and managers or bureaucrats directly involved).

Plantations in Africa - including those peasant and neo-kulak schemes so tightly organised as to be de facto disguised plantations - always have higher capital and recurrent costs per acre than neo-kulaks and, a fortiori, than peasants. Only for some crops and under special conditions - sisal, tea and sugar fairly commonly; wheat, rice, palm oil, rubber less often does higher output per acre offset these costs from a micro viewpoint, and even then the higher import component in costs (especially since 1973) raises questions about national economic viability.

The need to pay low wages (given higher ratios of other costs to production) and the authoritarian production relations pattern create further problems in production, as well as in socio-political terms. Land is not in general scarce in Africa (especially around plantations); thus for peasant households opportunities to increase their cash income dramatically reduces labour availability. This has been very marked in

${ }^{9}$ This labour shortage is fairly good corroboratory evidence to the weak statistical data suggesting peasant household relative (and to 1978 absolute) gains.
Tanzania over 1976-81 with special reference to the more unpleasant jobs - sisal and cane cutting, and tea plucking. ${ }^{9}$ It also affects neo-kulaks and 'modern commercial' farmers - eg in coffee picking at Arusha - but to a lesser degree.

The 'modern commercial' or settler model has even less economic viability. Even under colonial conditions with massive preferences the typical rate of return on capital (after allowing a manager-level labour income to the farmer) is -5 per cent to +5 per cent. This was, and is, true of Kenya and Zambia (where there are many African successors to the settler farmers), to Rhodesia and now Zimbabwe, and to Namibia and South Africa. Only subsidies, preferential access to inputs/markets and stock capital provision can keep this sector alive, let alone growing. As to do so eats up most of the resources available to agriculture (especially programme and policy design) the effect on overall output growth is dubious, while that on external account vis-à-vis peasant production) is unambigously negative - the import content is much higher.

The three capitalist roads all share two general problems:

- if successful as general agricultural output approaches, they would create a 50 per cent redundant population (ex-peasant producers) whom they could not employ, ${ }^{10}$ but whose access to markets they would monopolise - hardly a route either to socio-political stability, or to domestic market growth of demand;

- mechanisation, intensive input packages and large-scale schemes are highly import intensive (up to 75 per cent of retail prices for sugar, 25 per cent of exfarm for grain - versus 5 per cent for peasants in the latter case - according to some estimates). Given the negative terms of trade shifts since 1973, their micro and especially their macro (national external balance) viability is open to the gravest doubt.

\section{Barriers to the Classic Socialist Transformation Approach}

The barriers to the capitalist plantation road and the caveats about mechanisation apply forcefully to central state farms, whether created from scratch or by takeover of plantations/settler farms. In Mozambique the result of concentrating agricultural sector resources on the state farm (as opposed to the communal or peasant household) has not been to maintain marketed output (indeed peasant marketed

\footnotetext{
${ }^{10}$ In the period of the 'Miracle Ivoirienne', the Ivory Coast had a labour shortage - over 50 per cent of all unskilled labour were temporary immigrants. The end of the labour shortage and of the miracle appear to coincide.
} 
output has held up much better), nor to ensure urban food supplies (imports have rocketed). It has prevented adequate attention to communal and household production and to supporting services (transport, inputs, procurement, supplies of consumer goods), with an arguably negative impact on transition toward socialism and on production - a case increasingly made in Mozambique Party and state circles. While some state farms/plantations have served specific purposes (usually in contexts where private plantations were viable) and do increase the public sector weight in the economy, this is no evidence of their usefulness as a conrol production tool, while their production relations are notoriously hard to transform to anything involving even sustained pre-socialist worker participation.

Both state farms and capital/input intensive peasant schemes suffer from the same problems of lack of data to make sound technical choices, low returns to capital and high import context as their capitalist variants. This is as true when collaborators are European socialists as when they are North Atlantic capitalist bilateral and multilateral technical assistance personnel (a point equally valid in terms of the antiparticipatory nature of almost all standard expert rural development advice, with partial exceptions in the cases of ILO, WHO, China, Yugoslavia and - in principle if unevenly in practice - Nordic bodies). Even when the term 'participation' is used the word seems to be defined as doing what others decide, or putting oneself (if a peasant) in a new context more conducive to effective coercion and exploitation.

Not surprisingly, therefore, state farms are often as bitterly opposed by peasants as capitalist plantations - and for much the same reasons. Both Lenin [1976:303,355,362] and Engels [quoted in Lenin 1976:228] warned against coercion under such conditions as damaging to the development of productive forces and social relations, warnings African experience seems to justify.

Communal production of main crops has an unsuccessful record broken only by cases in which the crop was introduced, or first commercialised, as a communal crop (eg in particular villages in Tanzania for maize, beans, tobacco) and there is no experience of household cultivation. For example, in 1979 one million Mozambicans (20 per cent of the probably peasant population) lived in communal villages, but only 70,000 ( 1.5 per cent) were producing crops communally, and in Tanzania 90 per cent of peasants are in organised villages with participatory and communal structures but under five per cent of

\footnotetext{
"The distribution is uneven - over half of villages have negligible communal crop production, perhaps 10 per cent over a quarter and 5 per cent over a half.
}

agricultural output (possibly under three per cent) is communal. ${ }^{11}$

The reasons are technical or technico-ideological. In a majority of cases noboby knows how to produce more effectively on a communal basis. Known models with few purchased inputs are household based; most appropriate inputs to be added are either just as effective for household use (eg seeds, fertiliser, insecticide, hand implements) or can be handled communally without joint production (eg oxen, smallscale irrigation, communal storage). Known largescale approaches are so intensive in purchased inputs and artisanal/managerial skill as to be inappropriate and unusable, and are seen as such. ${ }^{12}$ Thus peasants cannot usually learn the value of communal crop production by seeing examples - on the contrary. As agricultural services (even when not biased against communal production) have no clearer ideas, and the village committee able on its own to work out viable new production relations, land use patterns and input mixes is unusual (albeit not unknown), the slowness of acceptance of communal production is not simply related to the 'peasant mentality'. When there are clear risks of loss and no clear chances of gain, peasants would be very foolish to shift. The inapplicability of the communal alternative thus prevents changes in consciousness, and reinforces any existing attitudes antagonistic to socialist transformation.

Provision of supporting services (as discussed in the first section above) by governments seeking a transition to socialism has been better than average in respect to water, health, education and support for communal investment projects, eg in Mozambique, Tanzania, Cape Verde, Zimbabwe. That does not hold for procurement, transport, storage or input supply, and very unevenly for 'incentive goods' allocations to rural areas (Tanzania and Mozambique do make allocations which reach rural centres ${ }^{13}$ - whether they then reach peasants is less clear). Whether their record is worse is unclear - private channel cost/surplus margins in Tanzania for main crops with no official channels (eg bananas, potatoes) are as high as, or higher than, marketing parastatal margins. Urban food deficits are as serious in Ghana and Nigeria as in Tanzania and Mozambique. But the failures do publicly discredit socialism, waste scarce personnel, create parasitic administrators and waste public sector resources. That capitalist performance is no better is

\footnotetext{
${ }^{12}$ Tractors seem to be an exception. As their gift for good performance often gravely damages a village's finances, they seem to play (unintentionally) the role of a sacred white elephant given by a Thai king to an unloved noble (ie, impose the ruinous expense, of a non-productive but non-returnable 'asset').

${ }^{13}$ Horror stories of too much cooking oil, sugar, khanga in rural areas in Tanzania are not typical of supply realities, but they do happen on occasion precisely because allocations to rural areas do exist in practice as well as on paper.
} 
little comfort to advocates or would-be architects and artisans of socialist transitions.

At a different level, a series of consciousness problems arising from objective conditions plagues advocates of standard Eurocentric models of transition to agrarian socialism. Most African peasant households are not sharecroppers, nor dependent on large farmers, in any way analogous to Latin American minifundistas although there are exceptions to this 'rule'. Nor except in the labour reserve economies and a handful of special cases (eg the Ismani maize zone in Tanzania) have they suffered directly from capitalist land grabbing. Except in the labour reserve cases (including those of Rwanda, Burundi and the Sahel where the land and the labour surplus are in different states, plus certain densely populated rural areas) the degree of exploitation of rural wage labour is limited, because there is a real option of entering peasant household production. Therefore, there is no general consciousness of domestic capitalist landlord/employer exploitation even vaguely comparable to that in much of Latin America, Asia or pre-socialist Central and Eastern Europe. Such a consciousness may be developing - eg in Kenya and Zimbabwe - but does not exist yet, and (as has usually been true elsewhere) tends to take peasant household oriented populist forms more often than socialist, ie China and Vietnam are no handier off-the-shelf tool kits than the Soviet Union (whether of war communism, the NEP or of collectivisation).

\section{Some Building Blocks Toward Communal/ Socialist Transformation?}

Must one then join the dirge - largely sung by wellpaid expatriates who have no share in the misery, often condemn their own sub-class members' past advice, and can walk away from the scene ${ }^{14}$ - on socialist transitions, egalitarianism, basic service provision and production in rural Africa? The chorus has eminent members, is broad church with as many left and right members and is the fashionable intellectual orthodoxy of the moment.

Not self-evidently. If one looks at rural development more generally results are by no means uniformly negligible, let alone negative in respect to social relations, productive forces and socialist transition.

First, broadening community size through encouraging, supporting and on occasions requiring shifts from isolated homestead to village settlements

\footnotetext{
${ }^{14}$ Precisely because the author is too committed for too long to feel able to walk away he is doubtless prone to the opposite error of objectively excessive hopefulness at the level of will, if not necessarily of intellect.
}

patterns - a prerequisite to organisation on control by any state or economic organ has been widely accepted (especially after the event) in several states, eg Mozambique, Guinea Bissau, Tanzania. It has however imperfectly and ambiguously - raised peasant consciousness, self-organisation and power $v i s-\grave{a}$-vis the bureaucracy, and - more often than not - rich peasants, as well as in many cases increasing women's self-consciousness, self-organisation and access to power, services, land and income.

Second, where seriously pushed (usually by socialist oriented governments) the improvements of rural basic services (adult and primary education, preventative and basic curative health, pure water) has been very marked (eg 10 to 65 per cent rural adult literacy in Tanzania 1961-81). Presumably a better educated, healthier peasantry used to demanding and getting the services it wants is likely to develop a different consciousness in respect to material constraints and to antagonistic sub-class and institutional interests. Four service areas (pure water, mother and child care, communal wood lots, universal literacy) have positive implications for reducing the subordination of women.

Third, the limited communal production of main crops is often paralleled by substantial communal activity in trade (crop buying and village retailing), transport, dairy herds and/or small scale manufacturing or servicing workshops. Even more notable are communal investment of labour, material inputs and money in housing, roads and bridges, water supply, health and education buildings, housing, small-scale irrigation, land clearing and afforestation (wood lot, crop bearing trees, watershed protection). In Tanzania half the villages have viable communal shops, and total rural communal investment is at least $\$ 150$ $200 \mathrm{mn}$ a year ( 3 to 4 per cent and 10 to 12 per cent of GDP and Fixed investment estimates which exclude it). This suggests that a wide range of communal production and expanded reproduction activities are carried out by the peasantry in countries of socialist orientation, with the likelihood of actual net communal benefits.

Fourth, some state enterprises have demonstrated that improved transport and procurement can cause explosive rises in marketed (and in these cases probably total) output - eg the 'new grain surplus' regions of Tanzania. ${ }^{15}$ Other have had dramatic success at production promotion or support - eg the Tanzania annual coffee growth trend over 1975/76$80 / 81$ has been 4.8 per cent whereas in the early 1970 s the agricultural advice was that coffee berry disease

\footnotetext{
is This output enhancement on Smith/Myint 'vent for surplus' lines does pose problems (especially since 1973) in respect to transport costs.
} 
would wipe out two-thirds of the existing output. CBD was controlled, general husbandry (unevenly) improved and new areas given (still weak) access to inputs and buyers. In short, there is no general record of institutional failure in managed market socialist attempts, just as it is false to argue that the capitalist 'free' market road has been a success in Africa.

To analyse what these patterns and events mean requires rather more careful observation and humility and rather less attempt to fit African contexts into European historic sequences (of whatever ideology) than has been usual to date. The point is not to avoid reading Marx and Engels and Lenin, but rather how to go about it. For example, Lenin's texts on the inadvisability of coercing middle peasants, on the rationale for the NEP [Lenin 1976, pp 235,354, $396 \mathrm{ff}$ ] as well as on the desirability, if possible, of evolving an efficient peasant family farming system along the lines of nineteenth century America [Lenin 1976, p 183] are perhaps more apropos to Africa than most of the more recent Marxian writing. There is an equal need to read serious African theorists and activists such as Cabral ${ }^{16}$ and Nyerere [see Nyerere 1967, 1968, 1973, 1977] paying attention to what they have argued and attempted in what context and why, especially when it conflicts with European socialist applied analysis, sequences and praxis. In particular, misinterpretations of Cabral as arguing that the petit bourgeoisie, as a class, would or could commit class suicide by becoming the proletariat in Guinea Bissau, or elsewhere, or Nyerere as developing an arcadian model to be copied rather than a mobilising myth (in the technical sense of that term) both mystify and win debating points at a high price in obfuscation of the cases and contexts in point, and prevent serious analysis of the viable strategies and tactics for achieving transitions to socialism in Africa more generally.

Certain basic theoretical premises may also require reappraisal. One is whether the agricultural sector in most African contexts does or can generate a net surplus. The evidence on household cash flow and government transactions in Tanzania suggests a negative answer [Wagao 1981] as do physical productivity levels in different sectors in many African countries. This is not to deny the sector's importance in producing basic commodities and in transforming the surpluses of other sectors into foreign exchange, and thus into specific fixed and circulating capital elements not producible locally. The answer (which is unlikely to be the same for all African countries or crops) is a critical one for policy.

\footnotetext{
${ }^{16}$ For an introduction see Davidson 1982.
}

Finally, if socialist transition is seen as participatory - in Cabral's sense as changing perceptions, consciousness and social relations - considerably more willingness to listen to and learn from peasants, and to consider sequences from their point of view is required. Hard-line production socialists seem to ignore or deny this even more frequently than pure capitalist intellectuals. When they at the same time decry 'socialism from above' an apparent practical contradiction arises which is not resolved by asserting that the peasants suffer from false consciousness (even if the assertion is in some objective and contextual sense valid). The record both of agricultural experts and socialist transition experts in Africa (including African ones) is uneven enough and the results of their efforts unsatisfactory enough to make the case for considering peasants as active subjects rather than passive objects, appear strong even on the narrowest pragmatic grounds.

\section{References}

Davidson, Basil, 1982, 'On revolutionary nationalism: the legacy of Cabral', in C. Stuart and L. Denzer, Radicalism in West Africa, Sage

Green, R. H., 1981, 'Magendo in the political economy of Uganda: pathology, parallel system or dominant sub-mode of production?', Discussion Paper 164, IDS Sussex

Harvey, C. et al, 1981, East and Southern African Agricultural Policy Papers, report to SIDA, IDS Sussex

Lenin, V. I., 1976, Alliance of the Working Class and the Peasantry, Foreign Languages Publishing House, Moscow

Myint, Hla, 1958, 'The classical theory of international trade and the underdeveloped countries', Economic Journal, June

Nyerere, J. K., 1967, Freedom and Unity, OUP

-1968, Freedom and Socialism, OUP

-1973, Freedom and Development, OUP

-1977, The Arusha Declaration - Ten Years After, Government Printer, Dar es Salaam

Wagao, J. H., 1981, 'Income Distribution in a Developing Country: the Case of Tanzania', unpublished DPhil thesis, University of Sussex

Wallace, T., 1980, 'Agricultural projects in Northern Nigeria', Review of African Political Economy, no 17

World Bank, 1981, Accelerated Development in sub-Saharan Africa: an Agenda for Action, Washington, (tables and statistical annex)

Note: numerous other sources and experiences beyond those cited speclflcally have been used. Particularly valuable were many of the papers for the April 1982 Review of African Polltical Economy Department of Politics and African Studies Unit, University of Leeds organlsed 'Transition to Socialism in Afriea' conference. 


\section{Books Received}

Gavin Kitching, Development and Underdevelopment in Historical Perspective, Methuen, London and New York, 1982

Ankie M. M. Hoogvelt, The Third World in Global Development, Macmillan, London, 1982

Henrik Secher Marcussen and Jens Erik Jorp, The Internationalisation of Capital: the prospects for the Third World, Zed Press, London, 1982

George Philip, Oil and Politics in Latin America: Nationalist Movements and State Companies, Cambridge University Press, 1982

Eric Nissen-Petersen, Rain Catchment and Water Supply in Rural Africa: a manual, Hodder and Stoughton, London, 1982

Just Faaland (ed), Population and the World Economy in the 2lst Century, Basil Blackwell, Oxford, 1982

Stephen Maxwell (ed), Scotland, Multinationals and the Third World, Mainstream Publishing, Edinburgh, 1982

Jorge Salazar-Carrillo, The Structure of Wages in Latin American Manufacturing Industries, The University Presses of Florida, 1982

Anthony Jennings and Thomas G. Wein (eds), The Challenge of Development in the Eighties: Our Response, Pergamon Press, Oxford, 1982

Michael Watts and Matthew Glen, Worked Examples in Data Response Questions for a Level Economics, Heinemann, London, 1982

Margaret Hardiman and James Midgley, The Social Dimensions of Development: Social Policy and Planning in the Third World, Wiley, Chichester, 1982

Stefan de Vylder, Agriculture in Chains: Bangladesh: a Case Study in Contradictions and Constraints, Zed Press, London, 1982

Richard Swift and Robert Clarke (eds), Ties that Bind: Canada and the Third World, Between the Lines, Toronto, 1982

Per Pinstrup-Andersen, Agricultural Research and Technology in Economic Development, Longman, London and New York, 1982

Alan Gilbert (ed) with Jorge E. Hardoy and Ronaldo Ramirez, Urbanisation in Contemporary Latin America: Critical Approaches to the Analysis of Urban Issues, Wiley, Chichester, 1982
Cahiers d'etudes Africaines $81-83$, 'Villes Africaines au microscope', editions de l'ecole des hautes etudes en sciences sociales, Paris, 1982

Jonathan Unger, Education under Mao: Class and Competition in Canton Schools, 1960-80, Columbia University Press, 1982

'Woman's subordination: Asian perspectives; Logos, vol 20 no 4, December 1981; Centre for Society and Religion, Colombo, Sri Lanka

Hans H. Landsberg and Joseph M. Dukert, High Energy Costs: Uneven, Unfair, Unavoidable?, Johns Hopkins, Baltimore, 1981

Kuang-Sheng Liao (ed), Modernisation and Diplomacy of China, Public Affairs Research Centre, The Chinese University of Hong Kong, 1981

Marilyn Carr, 'A ppropriate technology and rural industrialisation', Occasional Papers $l$, Intermediate Technology Development Group, London, 1982

D. W. J. Miles, 'A ppropriate technology for rural development: the ITDG experience', Occasional Paper 2, Intermediate Technology Group, London, 1982

John Tanner, The Parrot and Long John Silver: how the policies of Mrs. Thatcher and President Reagan are damaging the poor in the Third World, World Development Movement, 1982

Rural Reconstruction, vol 15 no 1, January 1982; Afro-Asian Rural Reconstruction Organisation, New Delhi, India

Keynote Speeches in conjunction with inauguration of Asian and Pacific Development Centre 17-19 August 1981, Kuala Lumpur

Desmond D'Abreo, People and Forests: the Forest Bill and a New Forest Policy, India Social Institute, New Delhi, 1982

Alfred de Souza, The Social Organisation of Aging among the Urban Poor, Indian Social Institute, New Delhi, 1982

Hanne Christensen, Survival strategies for and by camp refugees: report on a six-week exploratory sociological field study into the food situation of refugees in camps in Somalia, UNRISD, Geneva, 1982

Gerard A. Nagelkerke, Netherlands Antilles: a Bibliography, 17th century-1980, Department of Caribbean Studies of the Royal Institute of Linguistics and Anthropology, Leiden, 1982

Jamal Khan, Public Management: the Eastern Caribbean experience, Department of Caribbean Studies of the Royal Institute of Linguistics and Anthropology, Leiden, 1982 